\title{
ウォータベルの形成に及ぼす界面活性剤の影響*
}

\author{
大 山 博 史*1, 庵 原 昭 夫*2
}

\section{Effects of Surfactant on Formation of Water Bell}

\author{
Hiroshi OYAMA and Akio IHARA*3 \\ ${ }^{* 3}$ Department of Mechanical Systems Engineering, Utsunomiya University, \\ 7-1-2 Yoto, Utsunomiya-shi, Tochigi, 321-8585 Japan
}

\begin{abstract}
Water bell which resulted from the equilibrium between surface tension and centrifugal acceleration was found by Felix Savart in 1833 for the first time. To investigate the effects of surfactant on water bell formation, we took photographs of the water bells for distilled water and dilute surfactant solutions with high-speed video camera and digital camera. From the analysis of these photos, it was found that the surface shapes at the same injection pressure were almost same in spite of an addition of surfactant and became very stable when the surfactant was added. Then we performed a numerical simulation based on the equilibrium of a liquid sheet. Results showed the closely coincidence with the calculated shapes and the measured ones.
\end{abstract}

Key Words : Jet, Free Surface Flow, Stability, Water Bell, Surfactant

\section{1. 緒 論}

ノズルから噴出させた円柱状の液体噴流を表面が平 らな円板に垂直に衝突させると, 円板上に薄い液体の 層が水平方向に向かって広がり，これが円板端より静 止雲囲気の大気中に流出することによって液膜が形成 される.このような方法により, 1833 年 Felix Savert $^{(1)}$ によって行われた実験的研究においてウォ 一タベルの存在が明らかにされ, 歴史上, この研究が ウォータベル研究の始まりとなった。形成された液膜 の形状がベル形になることからウォータベルと呼ばれ ている。この液膜の形成や安定性は, 複雑な液体微粒 化過程の重要な要素の一つであるため，これらの問題 は今もなお, 興味深いものである(2).

このウォータベルに対して Clanet ${ }^{(3)}$ は, 蒸留水を 用いて，ウォータベルの形状に及ぼす噴流速度，噴流 直径, 円板直径の影響ならびにウォータベルが形成さ れる条件を明らかにし，さらに液膜に働く力の釣合い からウォータベルの形状に対する解析的な解を与えて

* 原稿受付 2004 年 3 月 15 日

*1 宇都宮大学大学院工学研究科 ( $321-8585$ 宇都宮市陽東 71-2).

*2 正員, フェロー, 宇都宮大学工学部.

E-mail : iharaaki@cc.utsunomiya-u.ac.jp
いる．しかし，ウォータベルの形状に大きな影響を与 えると考えられる表面張力を変化させた場合について は言及していない。

よって, 本研究では, 蒸留水に界面活性剤を添加し た水溶液を用いてウォータベルを形成し，高速度ビデ オカメラお.よびディジタルカメラによる撮影を行い, 液膜の形状を観測, 比較することによりこの形状に及 ぼす界面活性剤の影響を明らかにする。そして，液膜 に働く力の釣合いの式を数值的に積分することによ り, Clanet ${ }^{(3)(4)}$ の解析解よりも広いパラメー夕領域で ウォータベルの形状を予測し，実験で得られたウォー タベルの形状と比較を行うことにより, 解析結果の妥 当性とウォータベル形成の理解を深める.

\section{2. おもな記 号}
$P_{0}$ ：噴射圧
$D_{0}:$ 噴流直径
$U_{0}:$ 噴流速度
$D_{i}:$ 円板直径
$g:$ 重力の加速度
$\rho:$ 液体密度
$\nu$ : 動粘度
$\sigma:$ 表面張力 


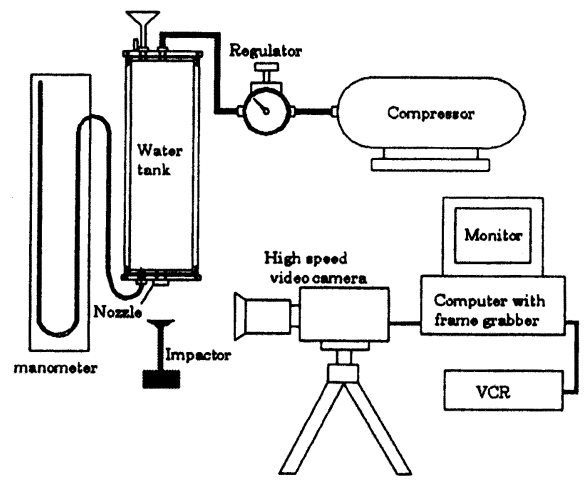

Fig. 1 Experimental setup

$$
\begin{aligned}
r & : \text { 水平方向の位置 } \\
z & : \text { 鉛直下向きの位置 } \\
h & : \text { ノズ出口から円板までの距離 } \\
\psi_{0} & : \text { 液膜出口角 } \\
R e & : \text { レイノルズ数 } \quad=D_{0} U_{0} / \nu \\
W e & : \text { ウェーバ数 }=\rho D_{0} U_{0}^{2} / \sigma \\
F r & : \text { フルード数 }=g h / U_{0}^{2}
\end{aligned}
$$

\section{3. 実験方法および装置}

実験装置の概略図を図 1 に示す。下ぶたにノズルを 取付けた貯水槽 (内径 $129.2 \mathrm{~mm}$, 高さ $450 \mathrm{~mm}$, 材 質：アクリル樹脂）に液体を注入し, 上部より圧縮空 気を注入し，ノズル入口にかかる圧力 (噴射圧 $P_{0}$ )を調 節することによって, ノズルから噴出する噴流の速度 を調整した. 圧力は貯気槽との貯水槽の間にレギュレ 一夕を介在させることにより貯水槽内の圧力を一定に 保った. また, ノズル入口圧力の測定は貯水槽下ぶた に取付けた水柱マノメータを用いて行った。液体噴流 の速度は噴流の流量を測定することにより決定した。 なお，噴流速度については，同一噴射圧に設定した場 合, 界面活性剤を加えても変わらないとし, 流量測定 は蒸留水のみで行った. 本実験で使用した噴射圧 $P_{0}$ とそのときの噴流速度 $U_{0}$ の実測值を表 1 に示す.な お，使用したノズルの構造と円板を図 2 に示す. 本実 験ではノズル出口直径 $4 \mathrm{~mm}$ のものを使用した。ま た, 液体噴流を衝突させる円板はさびにくいという性 質から黄銅を用いて製作し, 噴流衝突面を注意深く磨 き, 角度 $30^{\circ}$ の鋭いふちを付けた. 使用した円板の直 径は, $20 \mathrm{~mm}$ である.ノズル出口から衝突円板まで の距離 $h$ は衝突前の噴流の収縮や加速を無視できる 範囲の, 約 $25 \mathrm{~mm}$ とした. 各噴流速度に基づいた, レイノルズ数およびフルード数を表 1 に示す. 本実験 では使用液体として蒸留水および界面活性剤を加えた
Table 1 Relation between the injection pressure and jet velocities

\begin{tabular}{|c|c|c|l|}
\hline Pressure(kPa) & $U(\mathrm{~m} / \mathrm{s})$ & $R e$ & $F r$ \\
\hline 0.7 & 126 & 4755 & 0.154 \\
\hline 1.3 & 1.59 & 6000 & 0.097 \\
\hline 1.9 & 1.85 & 6981 & 0.07 \\
\hline 2.5 & 2.06 & 7774 & 0.058 \\
\hline 3.1 & 230 & 8679 & 0.046 \\
\hline 3.7 & 2.48 & 9358 & 0.040 \\
\hline 4.3 & 2.68 & 10113 & 0.034 \\
\hline
\end{tabular}

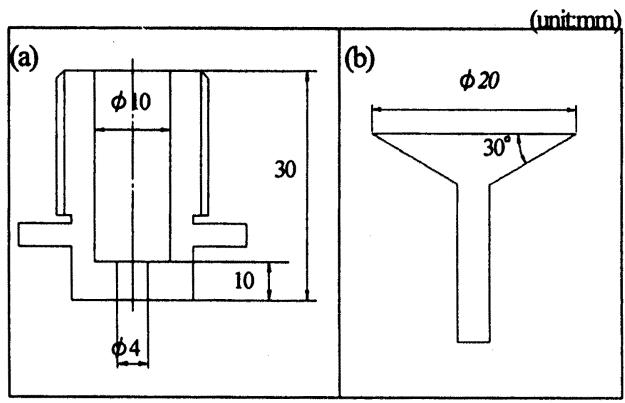

Fig. 2 Shape of (a) nozzle and (b) impactor, and its dimensions

水溶液を用いた。界面活性剤は, 臭化セチルトリメチ ルアンモニウム (分子量 364.45) を使用した. 蒸留水 および界面活性剤添加水溶液の表面張力は液滴法によ り測定した。また，実験中の液温は $18.0 \pm 3.0^{\circ} \mathrm{Cであ}$ るので以下すべての場合で $18.0^{\circ} \mathrm{C}$ 物性值を用いて 考察する. 表面張力の測定值と使用した液体の物性 值 ${ }^{(5)}$ を表 2 に示す. 噴流を円板中心に衝突させ, 形成 された液膜の撮影には高速度ビデオカメラおよびディ ジタルカメラを使用した. なお, ディジタルカメラに よる撮影では, 以下断りがなければすべてシャッタス ピード $1 / 30$, 絞り 2.5 , 照明はライトをつねに当てた 状態で行った。

\section{4. 実験結果および考察}

\section{$4 \cdot 1$ 静的形状について}

$4 \cdot 1 \cdot 1$ 噴射圧の影響 使用液体として蒸留水お よび界面活性剤水溶液 $100 \mathrm{ppm}$ を用い, 噴射圧を変 化させた場合のウォータベルの形状変化を図 3 に示 す. 図 3 の基準寸法はすべて同じである，蒸留水を用 いた場合, 図 3 に示すように噴射圧を増加させていく とそれに伴い液膜の広がりが大きくなっていくのがわ かる.また, 図 3(a)〜 ( c ) は液膜が閉じたベルにな 
Table 2 Physical properties of test liquid $\left(18.0^{\circ} \mathrm{C}\right)$

\begin{tabular}{|r|c|c|c|}
\hline \multicolumn{1}{|c|}{ Test solution } & $\sigma(\mathrm{N} / \mathrm{m})$ & $\rho\left(\mathrm{kg}^{3}\right)^{3}$ & $\nu\left(\mathrm{m}^{2} / \mathrm{s}\right)$ \\
\hline Distilled water & 0.073 & & \\
\cline { 1 - 2 } Surfactant(10ppm) & 0.056 & & \\
\cline { 1 - 2 }$(20 \mathrm{ppm})$ & 0.048 & \multirow{2}{*}{998.6} & \multirow{2}{*}{$1.06 \times 10^{6}$} \\
\hline$(30 \mathrm{ppm})$ & 0.042 & & \\
\cline { 1 - 2 }$(60 \mathrm{ppm})$ & 0.035 & & \\
\cline { 1 - 2 }$(100 \mathrm{ppm})$ & 0.033 & & \\
\hline
\end{tabular}

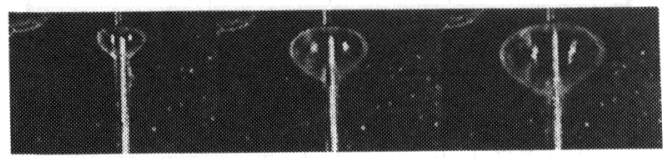

(a) $0.7 \mathrm{kPa}$

(b) $1.3 \mathrm{kPa}$

(c) $1.9 \mathrm{kPa}$

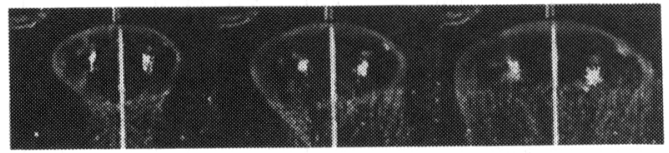

(d) $2.5 \mathrm{kPa}$

(e ) $3.1 \mathrm{kPa}$

(f) $3.7 \mathrm{kPa}$

Fig. 3 Configuration of water bell (distilled water)

(a) $R e=4755, W e=87$ (b) $R e=6000, W e=138$

(c) $R e=6981, W e=187$ (d) $R e=7774, W e=232$

(e) $R e=8679, W e=289$ (f ) $R e=9358, W e=337$

っているが, ( d )〜 ( f ) ではウォータベルの下部にお いて液膜が分裂し, 液滴となって散らばっていくよう すを観察することができる。これを開いたべルと呼 ぶ. 次に, 図 4 は界面活性剤水溶液 $100 \mathrm{ppm}$ を用い た場合であり，蒸留水の場合と同様に噴射圧の増加に

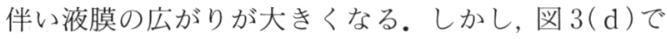
は開いたベルを観察することができたが, 図 4(d)で は噴射圧が等しいにもかかわらず，閉じたベルになっ ていることがわかる．噴射圧を増加させると，ウォー タベルの形状は本質的に変化しないまま液膜の広がり が大きくなっていき，ある噴射圧より大きくなるとウ オータベルの下部において液膜の分裂が生じる。しか し, 界面活性剤を加えることによって液膜が分裂しに くくなるということがわかる.

$4 \cdot 1 \cdot 2$ 界面活性剂の影響 $4 \cdot 1 \cdot 1$ 項で示した界 面活性剂の影響を明らかにするために噴射圧 $4.3 \mathrm{kPa}$ において, 蒸留水および界面活性剤水溶液(濃度 20 , $60,100 \mathrm{ppm})$ におるウォータベルを比較したもの が図 5 である。この写真から明らかに界面活性剤の濃 度の増加とともに液膜が分裂しにくくなっていること がわかる，その原因として，表面張力の低下により，
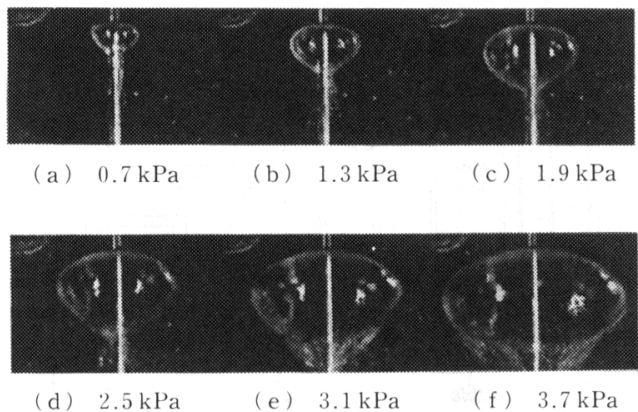

Fig. 4 Configuration of water bell $(100 \mathrm{ppm})$

(a) $R e=4755, W e=192$ (b) $R e=6000, W e=306$ (c) $R e=6981, W e=414$ (d) $R e=7774, W e=514$ (e ) $R e=8679, W e=640$ (f) $R e=9358, W e=744$

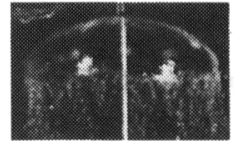

(a) distilled water

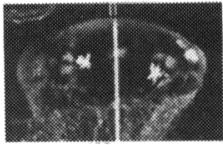

(c) $60 \mathrm{ppm}$

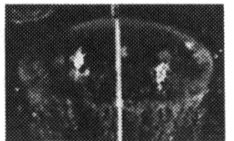

(b) $20 \mathrm{ppm}$

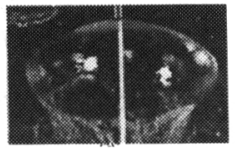

(d) $100 \mathrm{ppm}$
Fig. 5 Influence of surfactant on bell configuration $\left(P_{0}=4.3 \mathrm{kPa}\right)$

$R e=10113$ and (a) $W e=393$ (b) $W e=598$ (c) $W e=820(\mathrm{~d}) W e=869$

液膜の表面エネルギーが低下したことによると考えら れる。また, 界面活性剤の棒状ミセルによるとされる じょう乱抑制効果 ${ }^{(6)} に よ り ，$ 層流状態が維持されるた め, 液膜が安定し, 分裂が抑制されるということが考 えられる。

$4 \cdot 1 \cdot 3$ 形状比較噴射圧は液膜の広がりに大き な影響を与え, また界面活性剤水溶液の濃度は液膜の 不安定性に影響を与えることがわかった。では，界面 活性剂は液膜の広がりにどのような影響を与えるのだ ろうか. 界面活性剤の影響として, 粘性や表面張力の 変化が考えられるがここでは表面張力以外の影響をで きるだけ少なくするために，比較的濃度の低い界面活 性剂水溶液を用いる。使用液体は蒸留水抢よび界面活 性剂水溶液(濃度 $10,20,30 \mathrm{ppm}$ ) である。ディジ夕 ルカメラにより撮影を行い, 写真から得られたウォー タベルの形状をグラフ上にプロットし，これらを重ね て比較する。一つのウォータベルの形状につき， 5 枚 程度の写真から得られたデー夕の平均值である.

図 6 は円板衝突面の中心を基準にして横軸に水平方 


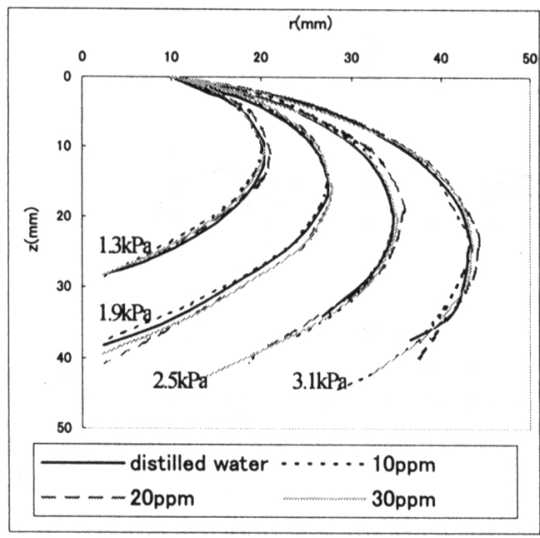

Fig. 6 Variation of the bell configuration $13 \mathrm{kPa}: R e=6000, W e=138$ (water), $180 \quad(10$ ppm), $210(20 \mathrm{ppm}), 240$ (30 ppm) $1.9 \mathrm{kPa}: R e=6981, W e=187$ (water), $244 \quad(10$ ppm), $285(20 \mathrm{ppm}), 325$ (30 ppm)

$2.5 \mathrm{kPa}: R e=7774, W e=232$ (water), 303 (10 ppm), 353 (20 ppm), 404 (30 ppm)

$3.1 \mathrm{kPa}: R e=8679, \quad W e=289$ (water), $377(10$ ppm), $440(20 \mathrm{ppm}), 503$ (30 ppm)

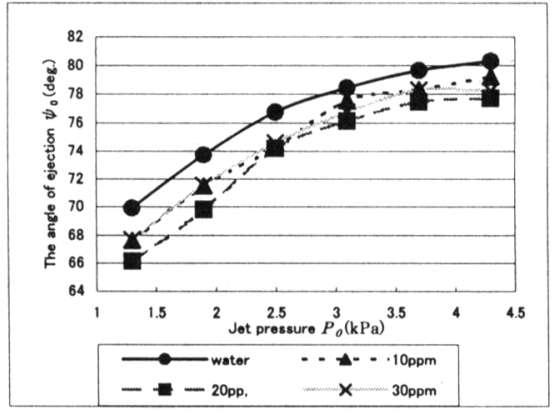

Fig. 7 Evolution of the angle of ejection $\psi_{0}$

向の距離 $r[\mathrm{~mm}]$, 縦軸に噴流の流れ方向(下向き)の 距離 $z[\mathrm{~mm}]$ をとってある.また,グラフ上には四つ の噴射圧 $1.3,1.9,2.5,3.1 \mathrm{kPa}$ について同時にプロ ットした. 図6より, 表面張力は大きな影響を与える であろうという予想に反して,いず机の噴射圧におい ても, 界面活性剤の量を変えても液膜の形状(広がり) はほとんど同じであるという結果が得られた。これは 後述するように, 表面張力が低下すると, 液膜の広が りは大きくなるはずであるが, 界面活性剤を加えると 円板端における平均流出速度が低下し, 当れによる液 膜の狭まりとが相殺しあったことによると考えられ る.

$4 \cdot 1 \cdot 4$ 液膜出口角度 $\psi_{0}$ について 液膜は円板か

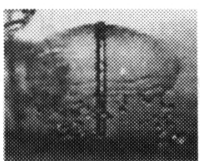

(a ) $0 \mathrm{~ms}$

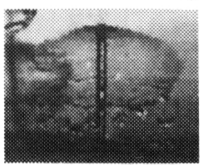

(d) $9.8 \mathrm{~ms}$

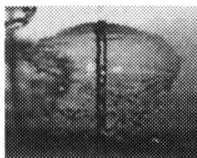

(g) $22.4 \mathrm{~ms}$

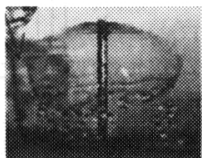

(b) $1.3 \mathrm{~ms}$

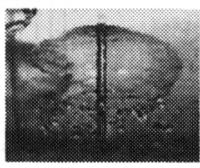

(e) $14.0 \mathrm{~ms}$

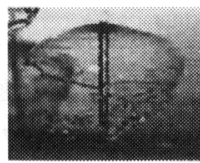

(h) $26.7 \mathrm{~ms}$

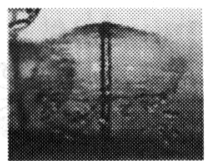

(c) $5.6 \mathrm{~ms}$

(f) $18.2 \mathrm{~ms}$

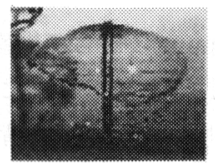

( i ) $30.9 \mathrm{~ms}$

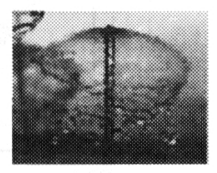

Fig. 8 Dynamic behavior of the liquid sheet (water, $\left.P_{0}=2.5 \mathrm{kPa}\right), R e=7774$ and $W e=232$

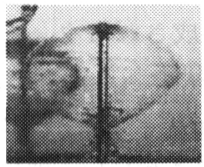

(a ) $0 \mathrm{~ms}$

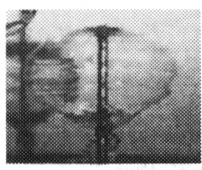

(d) $15.3 \mathrm{~ms}$

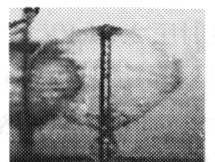

(b) $5.1 \mathrm{~ms}$

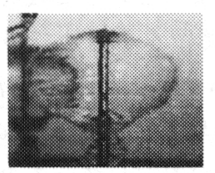

(e ) $20.4 \mathrm{~ms}$

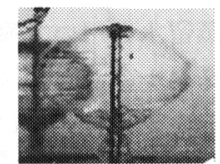

(c) $10.2 \mathrm{~ms}$

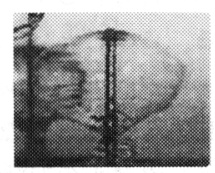

(f) $25.5 \mathrm{~ms}$
Fig. 9 Dynamic behavior of the liquid sheet (100 ppm, $\left.P_{0}=2.5 \mathrm{kPa}\right), R e=7774$ and $W e=514$

ら離脱するとき液体噴流の軸と $\psi_{0}$ (図 10 参照)の角度 をなす。噴射圧によるこの角度の影響の受けやすさは 図 3，4 より明らかであるが，界面活性剤による影響は どのように受けるのかを調べる。使用液体は蒸留水お よび界面活性剂水溶液 (濃度 $10,20,30 \mathrm{ppm}$ ) である. 平均化の手法はベル形状を求めた場合と同じである. 図 7 は, 横軸に噴射圧 $P_{0}$ を, 縦軸に液膜出口角度 $\psi_{0}$ をとってある。図 7 より, 界面活性剤水溶液のほうが 蒸留水に比べて, いずれの噴射圧においても $\psi_{0}$ が小 さくなっていることがわかる。これは, 円板端での液 体の慣性力が界面活性剤を加えると低下したことを意 味する。

$4 \cdot 2$ 動的形状について 次に噴射圧を $2.5 \mathrm{kPa}$ に固定して, 蒸留水および界面活性剂添加水溶液 100 


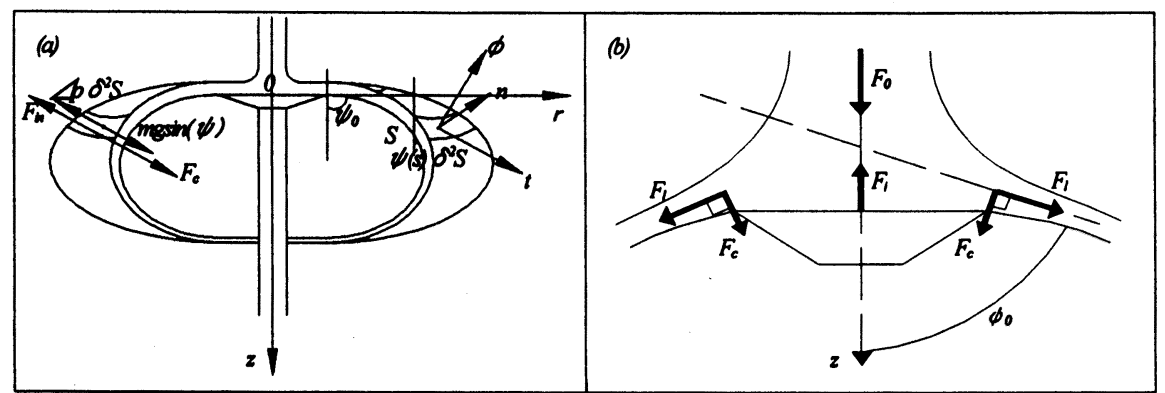

Fig. 10 Equilibrium of a liquid sheet element: (a) far from the edge ( $b$ ) at the edge of the impactor

$\mathrm{ppm}$ に対して撮影されたウォータベルの動的形状を 図 8 および図 9 に示す。撮影は高速度ビデオカメラを 用いて行った。背景にもう一つのウォータベルが写さ れているがそれは本体の影である。

蒸留水の場合には図 8(b)の矢印で示した部分から, 形成された液膜が徐々に分裂していくようすを観察で

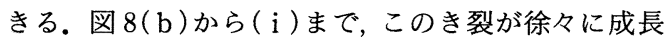
し, 液膜が分裂していく様相が示される。このように, 蒸留水を用いて噴射圧 $2.5 \mathrm{kPa}$ で形成されるウォー 夕ベルの液膜は図 8(a)のような形状を基本形とし, その後, 形成されていた液膜が突然分裂した後, 徐々 に基本形に戻万うとする，あるいは基本形に戻る前に さらに分裂してしまうということをつね繰返してい る.このことは, 蒸留水を用いて観測したすべてのウ オータベルについていえる. 界面活性剤添加水溶液 $100 \mathrm{ppm}$ を用いた場合には蒸留水の場合に比べてウ オータベルの形状が安定しているのを観測することが できる。これは界面活性剤を加えたことにより液膜の 不安定化が抑制されたことによる. しかしながら, 蒸 留水と同様に界面活性剂添加水溶液においてもつねに 液膜が波打っているのを観測することができた。

\section{5. 理 論 解 析}

$5 \cdot 1$ 理論式の導出 ウォータベルの液膜に働く 力の釣合い式の導出は文献 ( 3 ) に詳しく述べられてい るが，それを数值積分する方法はこの研究で新しく考 案したことなので，それらについて述べる。

図 10 (a) を用いて考える.今, $z$ 軸が噴流の流れの 方向(下向き)にとられている. 液膜上の位置 $s に お ~$ いて, 連続の式より

$$
r e u=\frac{1}{8} D_{0}^{2} U_{0}
$$

となる.ここで $r, e, u$ はそれぞれ半径方向の位置, 円板のふちからの距離 $s に お け る$ 液膜の厚さ, その位 置での局所的な流速を意味している．この流速 $u$ は,

$$
\begin{array}{r}
\text { ベルヌーイの式より } \\
u^{2}=u_{e}^{2}+2 g z \cdots
\end{array}
$$

と表すことができる。ここで $u_{e}=\sqrt{I\left(r_{i}\right) / h\left(r_{i}\right)}$ は円 板上での運動量を考慮した，円盤のふちにおける液膜 の平均流速である. $I\left(r_{i}\right)$ は式 $(3)$ で示される運動量 積分值に対応する量であり, $h\left(r_{i}\right)$ は円板ふちにおけ る液膜の厚さである.

$$
I(r)=\int_{0}^{h(r)} u(r, z)^{2} d z
$$

$I\left(r_{i}\right)$ および $h\left(r_{i}\right)$ は，通常の層流境界層理論から計 算できて，

$$
\begin{aligned}
& I\left(r_{i}\right)=\frac{R e}{246.5} \frac{D_{0}^{4}}{\left(r_{i}^{3}+l^{3}\right) r_{i}} U_{0}^{2} D_{0} \\
& h\left(r_{i}\right)=D_{0} \frac{4.83}{\operatorname{Re}} \frac{r_{i}^{3}+l^{3}}{D_{0}^{2} r_{i}} \quad \ldots \ldots \ldots . . . . . .
\end{aligned}
$$

で示される(7). また, $l \approx 0.329 D_{0} R e^{1 / 3}$ である.

次に, 図 10 に示されている微小面要素 $\delta^{2} S$ につい て考えると, $n$ 方向の平衡状態は, 表面張力による $F_{c}$ $=2 C \sigma \delta^{2} S$ と重力 $m g \sin (\psi)$, 遠心力 $m u^{2} / R_{c}$ そして 圧力差 $p \delta^{2} S$ の釣合いによって起こる.よって

$$
(2 C \sigma-p) \delta^{2} S+m g \sin (\psi)=m \frac{u^{2}}{R_{c}}
$$

と表すことができる.ここで $m=\rho \delta^{2} \mathrm{Se}$ は微小要素 の質量で, $R_{c}$ は垂線 $n$ 上の長さで $z$ 軸と交差する点 と液膜との間の距離で, $C=1 / R_{c}+\cos (\phi) / r$ は平均 曲率である．また $p$ はべルの内側と外側との圧力差 である.この圧力差はべルが開いているときは零であ るが, 閉じたべルの場合は表面張力の影響により零で はなくなる。

代表速度として $U_{0}$ を用い, 代表長さとして $L=$ $D_{0} W e / 16$ を用いると上式 (2)，（5）はそれぞれ

$$
\begin{aligned}
& \tilde{u}^{2}=\tilde{u}_{e}^{2}+2 \beta \tilde{z} \\
& (\tilde{u}-\tilde{r}) \frac{d \psi}{d \tilde{s}}=-\cos (\phi)+\alpha \tilde{r}-\beta \frac{\sin (\psi)}{\tilde{u}}
\end{aligned}
$$

となる.ここで, $\alpha=p L(2 \sigma)$ は無次元化された圧力差 
であり, $\beta=g L / U_{0}^{2}$ は無次元化された重力の加速度で ある. $\tilde{u}_{e}=\sqrt{I\left(r_{i}\right) /\left(h\left(r_{i}\right) U_{0}^{2}\right)}$ は, 式 $(4),(5)$ より

$$
\tilde{u}_{e} \approx 0.812 \frac{1}{1+3.5\left(X / R^{1 / 3}\right)^{3}}
$$

となる $\left(X=D_{i} / D_{0}\right)$ ，すべての無次元量は，角度 $\psi$ を 除いて記号チルドで示されている. また，幾何学的関 係により

$$
\begin{aligned}
& \frac{d \tilde{z}}{d \tilde{s}}=\cos \psi \\
& \frac{d \tilde{r}}{d \tilde{s}}=\sin \psi
\end{aligned}
$$

と表すことができる。

$5 \cdot 2$ 数値計算 以上のようにして $\phi, \tilde{z}, \tilde{r}$ を $\tilde{s}$ の関数と考えて，式 $(7) ，(9) ，(10)$ を数値的に解 く．連立常微分方程式の解法にはミルンの方法を用い た。なお，計算には初期条件として液膜出口角 $\psi_{0}$ が 必要となり,これには図 7 に示した実測值を用いる。 計算は蒸留水および界面活性剂水溶液 $10 \mathrm{ppm}$ を用い た場合について行った。物性値等は実験と同じものを 使用した。それらは次のとおりである。

密 度 $\rho=998.6 \mathrm{~kg} / \mathrm{m}^{3}$

動粘度 $\nu=1.06 \times 10^{6} \mathrm{~m}^{2} / \mathrm{s}$

表面張力

蒸留水 $\sigma=0.073 \mathrm{~N} / \mathrm{m}$

界面活性剂水溶液 $10 \mathrm{ppm} \quad \sigma=0.056 \mathrm{~N} / \mathrm{m}$

噴流直径 $D_{0}=4.0 \times 10^{3} \mathrm{~m}$

円板直径 $D_{i}=20.0 \times 10^{3} \mathrm{~m}$

噴流速度 $U_{0}=1.59 \mathrm{~m} / \mathrm{s}$

重力の加速度 $g=9.8 \mathrm{~m} / \mathrm{s}^{2}$

液膜出口角

蒸留水 $\psi_{0}=69.9^{\circ}$

界面活性剂水溶液 $10 \mathrm{ppm} \quad \psi_{0}=67.6^{\circ}$

\section{$5 \cdot 3$ 形状解析の結果および実験結果との比較}

蒸留水の場合の計算結果と実測値を図 11 に示す. 図 11 中の $p$ は液膜内外の圧力差を示す. ウォー夕べ ルが開いている場合には $p=0$ となるが, 閉じた場合 には表面張力の分だけ圧力差が発生する，計算結果も $p=0$ とした場合，実験値と若干の差が生じて，計算値 は小さくなる．pをわずかずつ増加させ, 形状が実験 值と一致する圧力差を求めると, $p=0.54 \mathrm{~Pa}$ となる. この場合に計測値と計算值はほとんど一致した。

界面活性剤を添加した場合の結果を図 12 に示す. 円板端における運動量積分値 $I$ に対し, 式(4)を用い て得られる $u_{e}$ を用いると計算結果 $(\mathrm{a})$ と実験結果と は大きく異なる結果となる。これは, 界面活性剤を加 えることによって円板表面流れにおいて表面摩擦抵抗

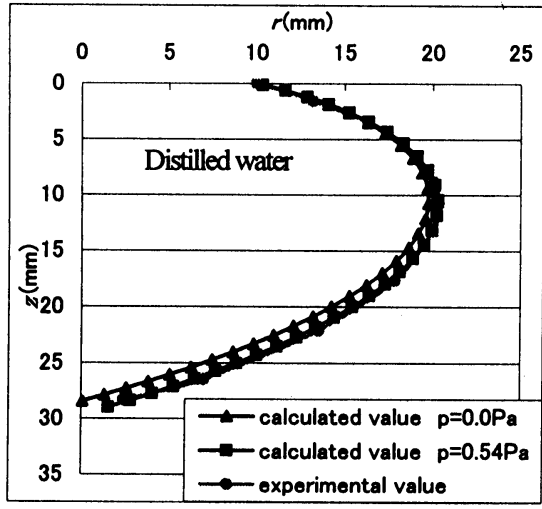

Fig. 11 Comparison of calculated value with experimental value (distilled water), $R e=6000$ and $W e=138$

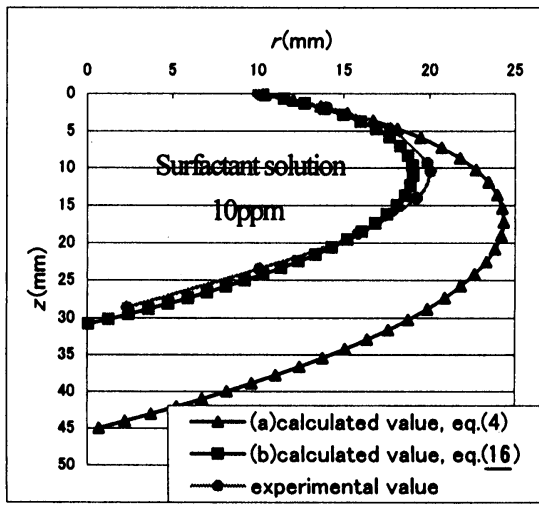

Fig. 12 Comparison of calculated value with experimental value $(10 \mathrm{ppm}), R e=6000$ and $W e=180$

が増大し, 運動量積分値 $I$ が大きく減少したことによ ると考えられる。これを裏付けるものとして，円板端 での液膜の流出角 $\phi_{0}$ が図 7 に示されるように, 蒸留 水の場合と比較する小さな值となっている.この流出 角 $\psi_{0}$ を使って $I$ を求める方法を考える. 図 $10(\mathrm{~b})$ を 参照すると, 円板端での鉛直方向の力の釣合いは次の ように書くことができる。

$$
\rho \pi D_{i} I\left(r_{i}\right) \cos \left(\psi_{0}\right)-\rho \pi D_{i} I_{\max }=-F_{i}+F_{c} \sin \left(\psi_{0}\right)
$$

ここで, $I_{\max }$ は粘性散逸がない場合の運動量積分值で 次のように書くことができる.

$$
I_{\max }=\frac{U_{0}^{2} D_{0}^{2}}{8 r_{i}}
$$

$F_{c}$ は表面張力による力で次のように書くことができ る.

$F_{c}=2 \sigma\left\{\frac{1}{r_{i}}+\frac{1}{h\left(r_{i}\right)}\right\} 2 \pi r_{i} h\left(r_{i}\right)$ 
$F_{i}$ は作用・反作用の法則から次のようになる。

$$
F_{i}=\frac{\pi \rho}{4} D_{0}^{2} U_{0}^{2}
$$

これらを式(12)に代入し, 整理して $I$ を求めると次の ようになる。

$$
I\left(r_{i}\right)=\frac{8 X I_{\max }}{W_{e}}\left\{1+\frac{h\left(r_{i}\right)}{r_{i}}\right\} \tan \left(\phi_{0}\right)
$$

$h\left(r_{i}\right)$ は式( 5$)$ より算出される值よりは大きくなっ ているはずであるが，算出方法が見つからないので式 （5）をそのまま使用する．また， $\psi_{0} に$ に対して計測値を 使用する.このようにして得られた $I$ を用いて, $\tilde{u}_{e}$ を算出してみると, 式（3)を用いた場合の $87 \%$, 大 幅に減少している.この減少した $\tilde{u}_{e}$ を用い, また液 膜内外の圧力差を表面張力が低下した分小さくなると して, $p=0.41 \mathrm{~Pa}$ をえた場合の計算結果 ( b ) を図 12 に示す．実験値とほほ一致していることがわかる。 以上より, 界面活性剤を添加すると, 円板表面上の流 れにおいて，大きな粘性散逸が生じることがわかる。

\section{6. 結 論}

円板に噴流を衝突させることによりウォータベルを 形成させ，この形状に及ほす界面活性剤の影響につい て, 写真により, 液膜の形状の観測を行った.さらに, 液膜に働く力の釣合いの式をもとにして数值計算を行 い, ウォータベルの形状を予測し, 実験によるウォー タベル形状と比較を行った. 以上より得られた結果の おもなものは次のとおりとなる。

（1）噴射圧の増大とともに液膜の広がりは大きく
なる。しかし，同一噴射圧のもとでは界面活性剤を加 えて表面張力を低下させて, 形状には大きな変化は発 生しない.

（2）界面活性剤を加えると液膜の不安定化が抑制 される。

（3）蒸留水を用いた場合, 通常の層流境界層理論 から算出される液膜平均流出速度を用い液膜内外の圧 力差を考慮すると計算さら求められたべル形状は実験 値とよく一致する.

（4）界面活性剤を加えた場合, 液膜流出角を用い て算出された液膜平均流出速度を用いると, 計算され たベル形状は実測値にほほ一致する。

\section{文献}

(1) Savart, F., Wemoire sur la constitution des veines liquids lancees par des orifices circulaires en mince paroi, Ann. de Chim., 53 (1833), 337-386.

（2）日本液体微粒化学会, アトマイゼーションテクノロジー, (2001), 3-18, 森北出版.

( 3 ) Clanet, C., Stability of Water Bells Generated by Jet Impacts on a Disk, Phys. Rev. Lett., 85 (2000), 51065109.

(4) Clanet, C., Dynamics and Sability of Water Bells, J. Fluid Mech., 430 (2001), 111-147.

（5）中村郁夫 - 大阪英男, 工学基礎 機械流体工学, (1999), 10, 共立出版.

（6）秋葉英男・尾崎公一・春木直人・浅野秀昭, 界面活性剤 水溶液の管内流動抵抗軽減と熱伝達，機論， 61-589 B (1995), 206-212.

( 7 ) Watson, E. J., The Radial Spread of a Liquid Jet over a Horizontal Plane, J. Fluid Mech., 20 (1964), 481-499. 